\title{
Effects of mepiquat chloride on yield and main properties of cottonseed under different plant densities
}

\author{
ZHAO Wenqing ${ }^{1,2}$, YAN Qiang ${ }^{1}$, YANG Hongkun ${ }^{1}$, YANG Xiaoni ${ }^{1}$, WANG Leran ${ }^{1}$, CHEN Binglin ${ }^{1,2}$, MENG Yali ${ }^{1,2^{*}}$ and \\ ZHOU Zhiguo ${ }^{1,2}$
}

\begin{abstract}
Background: Cottonseed oil and protein content as well as germination traits are major indicators of seed quality. However, the responses of these indicators to plant density and mepiquat chloride (MC) are still uncertain. To investigate plant density and $\mathrm{MC}$ effects on cottonseed yield and main quality parameters, we conducted a twoyear field experiment including four plant densities $\left(1.35,2.55,3.75\right.$ and 4.95 plants. $\left.\mathrm{m}^{-2}\right)$ and two doses of MC $(0$ and $\left.135 \mathrm{~g} \cdot \mathrm{hm}^{-2}\right)$ in Dafeng, Jiangsu Province, in 2013 and 2014.

Results: The application of MC reduced plant height, fruit branch length and fruiting branch number under different plant densities, resulting in a lower and more compact plant canopy. Cottonseed yield showed a nonlinear increase as plant density increasing and achieved the highest value at 3.75 plants. $\mathrm{m}^{-2}$, regardless of MC application. No significant interactions were found between plant density and $\mathrm{MC}$ for cottonseed yield and quality parameters. The 100-seed weight, cottonseed oil content and vigor index significantly decreased as plant density increased, while these parameters significantly increased with MC applying under different plant densities. Seed vigor index was positively correlated with 100-seed weight and seed oil content across different plant densities and MC treatments.

Conclusions: Thus, application of MC could realize a win-win situation between cottonseed yield and main quality parameters under various densities; and plant density of 3.75 plants $\cdot \mathrm{m}^{-2}$ combined with $135 \mathrm{~g} \cdot \mathrm{hm}^{-2}$ of $\mathrm{MC}$ applying is optimal for high cottonseed yield and quality in this cotton production area.
\end{abstract}

Keywords: Mepiquat chloride, Plant density, Cottonseed yield, Oil content, Seed germination

\section{Background}

Cotton (Gossypium hirsutum L.) is the most significant commercial crop globally (Hu et al. 2017). Cottonseeds provide the second and fifth largest potential source of plant protein and oil producing in the world, respectively ( $\mathrm{Li}$ et al. 2009a). This makes the seeds the second economic importance among the cotton products and gives cotton growers more opportunities to increase returns from cotton production (Rast 1917; Stansbury et al. 1954; Zhao and Guo 2011). In cottonseeds, the oil content is $30 \% \sim 40 \%$, and the protein content is $40 \%$

\footnotetext{
* Correspondence: mengyl@njau.edu.cn

${ }^{1}$ Key Laboratory of Crop Ecophysiology and Management Ministry of Agriculture, Nanjing Agricultural University, Nanjing 210095, Jiangsu, China ${ }^{2}$ Jiangsu Collaborative Innovation Center for Modern Crop Production (JCIC-MCP), Nanjing Agricultural University, Nanjing 210095, Jiangsu, China
}

$50 \%$ of the seed dry weight. They could offer plenty resources for ruminant feedstock, additional food and renewable biofuels (Chen et al. 2015). Cottonseeds are also the fundamental of cotton production because healthy and stronger seedlings would be a fantastic support for the subsequent cotton plant growth (Bewley 1997; Sawan 2016). Seed germination requires carbohydrate for organ construction until seedlings could establish itself as a self-sufficient organism (Bewley 1997). Seed with larger size has a higher germination rate and vigor index that enables seedling grow rapidly for organogenesis (Bewley 1997). However, the yield and quality of cottonseed, which should be paid more attention to, were neglected in both cotton research and production (de Faria et al. 2013; Thomas et al. 2013). 
Cottonseed yield and quality form in the flowering and boll forming stage. They are influenced by genetic (Guo et al. 2013; Zhao and Guo 2011), environmental conditions (Li et al. 2009a) and crop management (Egelkraut et al. 2004; Sawan et al. 1993). Among all these factors, crop management including plant density and mepiquat chloride (MC) applying are more regulable strategies, altering cotton source-sink balance and regulating growth of cotton (Gwathmey and Clement 2010; Tung et al. 2018).

It is well known that high plant density could increase competition for light and nutrients (Mao et al. 2014; Siebert and Stewart 2006), and lead to excessive vegetative growth and mutual shading. High plant density decreased lint yield, boll weight and boll number per plant because of low boll setting percentage. Optimal plant density increased lint yield by raising boll number per area (Bednarz et al. 2006; Dong et al. 2010; Ren et al. 2013). In regard to cottonseed yield and quality, the results were inconsistent. Dong et al. (2005) found that the maximum cottonseed yield was obtained at optimum plant density. Sawan et al. (1993) observed a decrease in cottonseed yield, seed index, seed protein content, oil and protein yields as plant density increased. While Zhu et al. (2010) reported that as plant density increased, cottonseed oil content decreased, but protein content showed a downward parabola trend.

MC is a plant growth retardant used extensively in cotton production. It can control excessive vegetative growth and promote cotton yield and quality (Ren et al. 2013). MC is applied at various cotton development stages, including seedling, squaring, flowering and boll forming stage. It could suppress cell elongation in the stem through inhibiting gibberellin (GA) biosynthesis (Rademacher 2000; Wang et al. 2014), thereby reducing shoot length (Almeida and Rosolem 2012) and plant height (Mondino et al. 2004; Reddy et al. 1996). Besides, MC application increased cotton light use efficiency through light interception and net photosynthetic rate (Mao et al. 2014), and increased cottonseed yield, seed oil content, protein content, and seed index (Sawan et al. 2001). Also, the cottonseed soaked with MC had a higher seed vigor (Wang et al. 2010).

With respect to the interactions between plant density and MC, most studies focused on cotton plant architecture, cotton yield, and fiber quality. Some studies have reported significant effects of plant density and $\mathrm{MC}$ on plant height (Mao et al. 2014) and lint yield (Xing et al. 2018; York 1983), but others did not find any significant interactions (Li et al. 2018; Ren et al. 2013; Siebert and Stewart 2006). Xing et al. (2018) reported that plant density of 7.5 to 10.5 plants. $\mathrm{m}^{-2}$ and MC application of 195 to $390 \mathrm{~g} \cdot \mathrm{hm}^{-2}$ was recommended for maximization of cotton fiber yield and quality in the Yellow River cotton-producing region. These varied results may related to that the optimum plant density was different among different cotton production regions, and the optimum plant density and use dosage of MC for different cultivars differed (Fu et al. 2015). However, the responses of cottonseed yield, seed oil and protein contents, seed germination character to plant density, $\mathrm{MC}$ and their interactions in the Yangtze River cotton planting region of China is still not clear. The main objective of this research was to evaluate the effects of plant density and MC on cottonseed yield, oil and protein content, seed germination traits. The results could give some suggestions for improving cottonseed yield and quality in the Yangtze River Valley of China.

\section{Results \\ Plant morphological characters and boll setting percentage}

The cotton plant height, fruiting branch number, fruiting node number significantly influenced by plant density, $\mathrm{MC}$, and plant density $\times \mathrm{MC}(P<0.05)$. Mean fruiting branch length was significantly affected by plant density and $\mathrm{MC}$, and the first fruiting branch height of cotton was only significantly affected by plant density (Table 1 ).

Compared with 1.35 plants. $\mathrm{m}^{-2}$, plant height increased by $4 \%, 8 \%, 14 \%$ under CK and by $14 \%, 19 \%, 26 \%$ under MC treatment, respectively, in 2.55, 3.75, 4.95 plants $\mathrm{m}^{-2}$. The first fruiting branch height increased by $74 \%, 79 \%$, $96 \%$ under CK and by 35\%, 41\%, 66\% under MC treatment, respectively, in $2.55,3.75,4.95$ plants. $\mathrm{m}^{-2}$. Mean fruiting branch length decreased by 14\%, 25\%, 40\% under CK and by $9 \%, 28 \%, 30 \%$ under MC treatment, respectively, in $2.55,3.75,4.95$ plants. $\mathrm{m}^{-2}$ (Table 1 ). MC significantly decreased plant height and mean fruiting branch length, but showed varied effects on the first fruiting branch height between 2013 and 2014. Compared with CK, MC decreased plant height by $22 \%, 15 \%, 14 \%$, and $14 \%$ in $1.35,2.55,3.75$, and 4.95 plants. $\mathrm{m}^{-2}$, respectively; and decreased mean fruiting branch length by $34 \%, 30 \%$, $37 \%$, and $24 \%$ in $1.35,2.55,3.75$, and 4.95 plants. $\mathrm{m}^{-2}$, respectively.

Fruiting branch number and fruiting node number significantly decreased as plant density increased (Table 1). At $2.55,3.75,4.95$ plants. $\mathrm{m}^{-2}$, fruiting branch number decreased by $2 \%, 10 \%, 14 \%$ under CK and by $6 \%, 7 \%, 14 \%$ under MC treatment, respectively; fruiting node number decreased by $14 \%, 28 \%, 41 \%$ under CK and by $19 \%, 27 \%, 41 \%$ under MC treatment, respectively, compared with 1.35 plants. $\mathrm{m}^{-2}$. MC significantly decreased fruiting branch number in both 2013 and 2014. Compared with CK, MC decreased fruiting branch number by $10 \%, 14 \%, 8 \%$, and $10 \%$ in $1.35,2.55,3.75$, and 4.95 plants. $\mathrm{m}^{-2}$, respectively. $\mathrm{MC}$ application decreased fruiting node number in 2014 but increased it in 2013. 
Table 1 Agronomic traits at boll opening stage as affected by mepiquat chloride (MC) and plant densities in Sikang 1

\begin{tabular}{|c|c|c|c|c|c|c|c|c|c|c|c|}
\hline \multirow[t]{2}{*}{$M C$} & \multirow[t]{2}{*}{ Plant density/(plant $\cdot \mathrm{m}^{-2}$ ) } & \multicolumn{2}{|c|}{ Plant height /cm } & \multicolumn{2}{|c|}{$\begin{array}{l}\text { First fruiting branch } \\
\text { height } / \mathrm{cm}\end{array}$} & \multicolumn{2}{|c|}{$\begin{array}{l}\text { Mean fruiting } \\
\text { branch length /cm }\end{array}$} & \multicolumn{2}{|c|}{$\begin{array}{l}\text { Fruiting node } \\
\text { number per plant }\end{array}$} & \multicolumn{2}{|c|}{$\begin{array}{l}\text { Fruiting branch } \\
\text { number per plant }\end{array}$} \\
\hline & & 2013 & 2014 & 2013 & 2014 & 2013 & 2014 & 2013 & 2014 & 2013 & 2014 \\
\hline \multirow[t]{4}{*}{ CK } & 1.35 & $128.2 \mathrm{~d}$ & $110.1 \mathrm{~b}$ & $16.0 \mathrm{c}$ & $5.5 \mathrm{c}$ & $65.8 \mathrm{a}$ & $50.4 \mathrm{a}$ & $112.6 \mathrm{a}$ & $85.0 \mathrm{a}$ & $24.6 \mathrm{a}$ & $18.2 \mathrm{a}$ \\
\hline & 2.55 & $133.6 \mathrm{c}$ & $114.1 \mathrm{~b}$ & $18.0 \mathrm{~b}$ & $13.0 \mathrm{~b}$ & $59.2 \mathrm{ab}$ & $41.3 \mathrm{~b}$ & $87.8 \mathrm{~b}$ & $80.2 \mathrm{a}$ & $23.8 \mathrm{ab}$ & $18.0 \mathrm{a}$ \\
\hline & 3.75 & 138.7 b & $119.1 \mathrm{ab}$ & $18.0 \mathrm{~b}$ & $13.5 \mathrm{ab}$ & $49.6 \mathrm{bc}$ & $37.8 \mathrm{~b}$ & $79.5 \mathrm{c}$ & $62.0 \mathrm{~b}$ & $22.7 \mathrm{bc}$ & $16.1 \mathrm{~b}$ \\
\hline & 4.95 & 145.6 a & $126.0 \mathrm{a}$ & $20.5 a$ & $14.5 a$ & $39.8 \mathrm{c}$ & $30.2 \mathrm{c}$ & $69.3 d$ & $48.0 \mathrm{C}$ & $21.4 \mathrm{C}$ & $15.6 \mathrm{~b}$ \\
\hline \multirow[t]{4}{*}{ MC $135 \mathrm{~g} \cdot \mathrm{hm}^{-2}$} & 1.35 & $100.5 d$ & $84.7 \mathrm{c}$ & $14.0 \mathrm{~b}$ & $10.0 \mathrm{~b}$ & $53.2 \mathrm{a}$ & 25.9 a & $125.5 \mathrm{a}$ & 66.8 a & $22.5 \mathrm{a}$ & 15.9 a \\
\hline & 2.55 & $123.3 \mathrm{c}$ & 88.6 bc & $15.5 \mathrm{~b}$ & $16.0 \mathrm{a}$ & $50.3 \mathrm{a}$ & $22.6 \mathrm{ab}$ & $112.5 \mathrm{ab}$ & $48.4 \mathrm{~b}$ & $22.1 \mathrm{a}$ & $14.3 \mathrm{ab}$ \\
\hline & 3.75 & $130.3 \mathrm{~b}$ & $92.6 \mathrm{ab}$ & $16.5 \mathrm{ab}$ & $16.5 a$ & $37.6 \mathrm{~b}$ & $18.9 \mathrm{~b}$ & $102.0 \mathrm{~b}$ & 43.4 bc & $21.3 \mathrm{ab}$ & $14.7 \mathrm{ab}$ \\
\hline & 4.95 & 135.9 a & 98.4 a & $18.5 \mathrm{a}$ & $20.0 \mathrm{a}$ & $36.2 \mathrm{~b}$ & $18.6 \mathrm{~b}$ & $82.2 \mathrm{C}$ & $34.4 \mathrm{C}$ & $20.8 \mathrm{~b}$ & $12.8 \mathrm{~b}$ \\
\hline \multicolumn{12}{|c|}{ Source of variance } \\
\hline \multicolumn{2}{|l|}{ Plant density } & $* *$ & ** & $* *$ & $* *$ & $* *$ & $* *$ & $* *$ & $* *$ & $* *$ & $* *$ \\
\hline \multicolumn{2}{|l|}{$M C$} & $* *$ & $* *$ & ns & ns & * & $* *$ & $* *$ & * & * & $* *$ \\
\hline \multicolumn{2}{|c|}{ Plant density $\times \mathrm{MC}$} & ** & * & ns & ns & ns & ns & $* *$ & $* *$ & * & ** \\
\hline
\end{tabular}

Values followed by the different letters within the same column are significant differences at 0.05 probability level; ${ }^{*}$ and ${ }^{* *}$ represent significant differences at 0.01 and 0.05 probability level, respectively; ns represents no significant differences

Thus, the cotton plant under high plant density will form a taller and compact plant structure, while MC spraying will form a shorter and compact plant structure.

\section{Cottonseed yield and yield components}

Plant density and MC significantly influenced the boll number per area, 100-seed weight, and cottonseed yield. No significant differences in seed number per boll was observed among plant density or MC treatments. Plant density $\times$ MC had no significant effects on cottonseed yield and yield components (Table $2, P<0.05$ ). Regardless of MC treatments, cottonseed yield increased and then decreased as plant density increased with the highest yield achieved at
3.75 plants $\mathrm{m}^{-2}$ in both growing seasons. Compared with 1.35 plants. $\mathrm{m}^{-2}$, cottonseed yield at 3.75 plants. $\mathrm{m}^{-2}$ increased by $44 \%$ averaged over MC treatments. There was no significant differences in cottonseed yield between 3.75 and 4.95 plants. $\mathrm{m}^{-2}$. Compared with CK, cottonseed yield with $\mathrm{MC}$ at $1.35,2.55,3.75$ and 4.95 plants. $\mathrm{m}^{-2}$ increased by $34 \%, 26 \%, 15 \%$ and $23 \%$ across year, respectively.

High plant density (3.75 and 4.95 plants. $\mathrm{m}^{-2}$ ) significantly increased boll number per area but reduced 100seed weight in both years, compared with 1.35 plants. $\mathrm{m}^{-}$ ${ }^{2}$ (Table 2). Meanwhile, application of MC increased not only boll number per area but also 100-seed weight at all plant densities.

Table 2 Effects of mepiquat chloride (MC) on cottonseed yield and yield components under different plant densities in Sikang 1

\begin{tabular}{|c|c|c|c|c|c|c|c|c|c|}
\hline \multirow[t]{2}{*}{$M C$} & \multirow[t]{2}{*}{ Plant density /(plant $\cdot \mathrm{m}^{-2}$ ) } & \multicolumn{2}{|c|}{ Boll number per area } & \multicolumn{2}{|c|}{ Seed number per boll } & \multicolumn{2}{|c|}{ 100-seed weight /g } & \multicolumn{2}{|c|}{ Cottonseed yield $/\left(\mathrm{kg} \cdot \mathrm{hm}^{-2}\right)$} \\
\hline & & 2013 & 2014 & 2013 & 2014 & 2013 & 2014 & 2013 & 2014 \\
\hline \multirow[t]{4}{*}{ CK } & 1.35 & $60.7 c$ & $48.0 \mathrm{C}$ & $31.0 \mathrm{a}$ & $31.7 \mathrm{a}$ & $10.2 \mathrm{a}$ & $10.2 \mathrm{a}$ & $1926 c$ & 1555 b \\
\hline & 2.55 & $73.9 \mathrm{~b}$ & $67.9 \mathrm{~b}$ & $31.6 \mathrm{a}$ & $34.5 \mathrm{a}$ & $9.7 \mathrm{~b}$ & $9.3 \mathrm{~b}$ & $2263 b c$ & $2180 \mathrm{a}$ \\
\hline & 3.75 & 85.7 a & 83.4 a & $33.0 \mathrm{a}$ & 33.9 a & $9.9 \mathrm{ab}$ & $9.1 \mathrm{~b}$ & $2810 a$ & 2562 a \\
\hline & 4.95 & $89.4 \mathrm{a}$ & $68.2 \mathrm{~b}$ & $32.0 \mathrm{a}$ & $35.0 \mathrm{a}$ & $9.2 \mathrm{c}$ & $9.0 \mathrm{~b}$ & $2622 a b$ & $2149 a$ \\
\hline \multirow[t]{4}{*}{ MC $135 \mathrm{~g} \cdot \mathrm{hm}^{-2}$} & 1.35 & $69.8 c$ & $65.0 \mathrm{~b}$ & 30.8 a & $32.8 \mathrm{a}$ & $11.0 \mathrm{a}$ & $10.7 \mathrm{a}$ & $2354 c$ & $2268 c$ \\
\hline & 2.55 & $86.5 \mathrm{~b}$ & 79.6 a & $33.2 \mathrm{a}$ & $32.5 \mathrm{a}$ & $10.7 \mathrm{a}$ & $9.8 \mathrm{~b}$ & $3068 a b$ & $2544 b c$ \\
\hline & 3.75 & $99.9 \mathrm{ab}$ & $91.0 \mathrm{a}$ & $32.5 \mathrm{a}$ & $33.0 \mathrm{a}$ & $10.0 \mathrm{~b}$ & $9.7 \mathrm{~b}$ & 3259 a & 2915 a \\
\hline & 4.95 & $102.7 \mathrm{a}$ & $82.1 \mathrm{a}$ & $31.0 \mathrm{a}$ & 34.7 a & $9.8 \mathrm{~b}$ & $9.6 \mathrm{~b}$ & $3112 \mathrm{a}$ & $2736 a b$ \\
\hline \multicolumn{10}{|c|}{ Source of variance } \\
\hline \multicolumn{2}{|l|}{ Plant density } & $* *$ & $* *$ & ns & ns & $* *$ & $* *$ & $* *$ & $* *$ \\
\hline \multicolumn{2}{|l|}{$M C$} & ns & $* *$ & ns & ns & * & * & * & $* *$ \\
\hline \multicolumn{2}{|c|}{ Plant density $\times \mathrm{MC}$} & ns & ns & ns & ns & ns & ns & ns & ns \\
\hline
\end{tabular}

Values followed by the different letters within the same column are significant differences at 0.05 probability level; ${ }^{*}$ and ${ }^{* *}$ represent significant differences at 0.01 and 0.05 probability level, respectively; ns represents no significant differences 


\section{Cottonseed oil and protein content}

Plant density and MC significantly influenced the 100embryo weight and cottonseed oil content. No significant differences in the kernel percentage and cottonseed protein content was observed among plant density, $\mathrm{MC}$, and plant density $\times \mathrm{MC}$ (Table $3, P<0.05)$. 100-embryo weight and cottonseed oil content decreased as plant density increased in 2013 and 2014, regardless of MC treatments. The cottonseed oil content reduced by $10 \%$ under CK and by $9 \%$ under $\mathrm{MC}$ at 4.95 plants $\cdot \mathrm{m}^{-2}$, relative to 1.35 plants $\mathrm{m}^{-2}$. Compared with $\mathrm{CK}$, cottttonseed oil content with $\mathrm{MC}$ at 1.35, 2.55, 3.75 and 4.95 plants. $\mathrm{m}^{-2}$ increased by $1 \%, 2 \%, 3 \%$ and $1 \%$ across year, respectively.

The relationship of cottonseed oil content between different fruiting branches (FB) varied in two years (Fig. 1). In 2013, the highest cottonseed oil content was observed in $>10 \mathrm{FB}$, followed by $6-10$ and 1-5 FB. In 2014, the highest oil content was observed in $6-10 \mathrm{FB}$, followed by 1-5 FB under 1.35 and 2.55 plants. $\mathrm{m}^{-2}$, and followed by $>10 \mathrm{FB}$ under 3.75 and 4.95 plants. $\mathrm{m}^{-2}$. This difference may relate to the higher temperature and more radiation in 2013 than 2014. While the different trends of cottonseed oil content between FB may relate to the more radiation received by the 1-5 FB under lower plant densities.

Meanwhile, a significant positive correlation between the cottonseed oil content and 100-seed weight on different FBs was observed in both 2013 and 2014 (Fig. 2), indicating that cottonseed with heavier weight will have a higher oil content.

\section{Cottonseed germination characteristics}

Plant density and MC significantly influenced GP, fresh weight of seedling and VI. No significant differences were observed in plant density $\times \mathrm{MC}$ interaction (Table $4, P<0.05$ ).
The germination characteristic indicators declined as plant density increased regardless of MC treatment. GP and Fresh weight of seedling under $\mathrm{CK}$ and $\mathrm{MC}$ treatment and VI under MC treatment significantly decreased under 4.95 plants. $\mathrm{m}^{-2}$ in 2013 and 2014. Compared with CK, the cottonseed GP, fresh weight of seedling, GI and VI increased by $19 \% \sim 42 \%, 1 \% \sim 19 \%, 15 \% \sim 30 \%$, and $11 \% \sim 42 \%$ at different plant densities with $\mathrm{MC}$ across year, respectively.

The relationship of cottonseed VI between different FBs varied in two years (Fig. 3), and the trend was similar with cottonseed oil content. The same trend of oil content and VI in different FBs and two years, along with the significant positive relationship between oil content and the 100-seed weight (Fig. 2), indicating that optimal plant density increase seed weight and oil content, which have greater potential for raising vigorous (stronger) seedlings.

\section{Discussion}

An optimal canopy structure is important for achieving a high cottonseed yield in cotton. In this study, increasing plant density from 1.35 to 4.95 plants $\mathrm{m}^{-2}$ lead to the increases in plant height and first fruit branch height and the reduction in fruit branch length (Table 1), indicating a tall and thin canopy structure produced by high plant density. A similar increase in plant height with increasing plant density was reported in cotton by Siebert and Stewart (2006). Besides, Mao et al. observed an enhancement tendency in plant height induced by larger plant population in the Yellow River cotton-producing region (2014). This effect may be due to a decrease in light penetration into the lower fruiting branch positions in the canopy under higher plant densities. A tall and thin canopy structure benefits light resource acquisition,

Table 3 Effects of mepiquat chloride (MC) on cottonseed oil content and protein content under different plant densities in Sikang 1

\begin{tabular}{|c|c|c|c|c|c|c|c|c|c|}
\hline \multirow[t]{2}{*}{$M C$} & \multirow[t]{2}{*}{ Plant density /(plant $\left.\cdot \mathrm{m}^{-2}\right)$} & \multicolumn{2}{|c|}{ 100-embryo weight /g } & \multicolumn{2}{|c|}{ Kernel percentage /\% } & \multicolumn{2}{|c|}{ Oil content $/ \%$} & \multicolumn{2}{|c|}{ Protein content $/ \%$} \\
\hline & & 2013 & 2014 & 2013 & 2014 & 2013 & 2014 & 2013 & 2014 \\
\hline \multirow[t]{4}{*}{ CK } & 1.35 & $5.5 \mathrm{a}$ & $6.4 \mathrm{a}$ & $54.1 \mathrm{a}$ & $62.6 \mathrm{a}$ & 31.9 a & 30.9 a & $40.1 \mathrm{a}$ & $40.1 \mathrm{a}$ \\
\hline & 2.55 & $5.5 \mathrm{a}$ & $5.6 \mathrm{ab}$ & 56.9 a & $60.6 \mathrm{a}$ & $31.4 \mathrm{ab}$ & $30.5 \mathrm{ab}$ & $41.8 \mathrm{a}$ & $42.1 \mathrm{a}$ \\
\hline & 3.75 & $5.3 \mathrm{a}$ & $5.3 \mathrm{~b}$ & $53.7 \mathrm{a}$ & $58.1 \mathrm{a}$ & $29.1 \mathrm{ab}$ & 29.9 b & $43.0 \mathrm{a}$ & $43.3 \mathrm{a}$ \\
\hline & 4.95 & $5.2 \mathrm{a}$ & $5.2 \mathrm{~b}$ & $57.1 \mathrm{a}$ & $58.1 \mathrm{a}$ & $27.4 \mathrm{~b}$ & $29.3 c$ & 40.8 a & $41.9 \mathrm{a}$ \\
\hline \multirow[t]{4}{*}{ MC $135 \mathrm{~g} \cdot \mathrm{hm}^{-2}$} & 1.35 & $5.8 \mathrm{a}$ & $6.3 \mathrm{a}$ & $53.2 \mathrm{a}$ & 58.9 a & $32.2 \mathrm{a}$ & $31.1 \mathrm{a}$ & $37.3 \mathrm{a}$ & $37.2 \mathrm{a}$ \\
\hline & 2.55 & $5.5 \mathrm{ab}$ & $6.1 \mathrm{a}$ & $51.9 \mathrm{a}$ & $62.0 \mathrm{a}$ & $32.5 \mathrm{a}$ & 30.8 a & $40.3 \mathrm{a}$ & $41.4 \mathrm{a}$ \\
\hline & 3.75 & $5.3 \mathrm{~b}$ & $6.1 \mathrm{a}$ & $53.2 \mathrm{a}$ & $62.5 \mathrm{a}$ & $30.7 \mathrm{ab}$ & 30.3 a & $41.4 \mathrm{a}$ & $42.1 \mathrm{a}$ \\
\hline & 4.95 & $5.2 \mathrm{~b}$ & $5.8 \mathrm{a}$ & $53.1 \mathrm{a}$ & $60.4 \mathrm{a}$ & 27.7 b & 29.7 a & 39.8 a & $38.3 \mathrm{a}$ \\
\hline \multicolumn{10}{|c|}{ Source of variance } \\
\hline \multicolumn{2}{|l|}{ Plant density } & $* *$ & $* *$ & ns & ns & $* *$ & * & ns & ns \\
\hline \multicolumn{2}{|l|}{$M C$} & * & * & ns & ns & * & $* *$ & ns & ns \\
\hline \multicolumn{2}{|c|}{ Plant density $\times$ MC } & ns & ns & ns & ns & ns & ns & ns & ns \\
\hline
\end{tabular}

Values followed by the different letters within the same column are significant differences at 0.05 probability level; ${ }^{*}$ and ${ }^{* *}$ represent significant differences at 0.01 and 0.05 probability level, respectively; ns represents no significant differences 


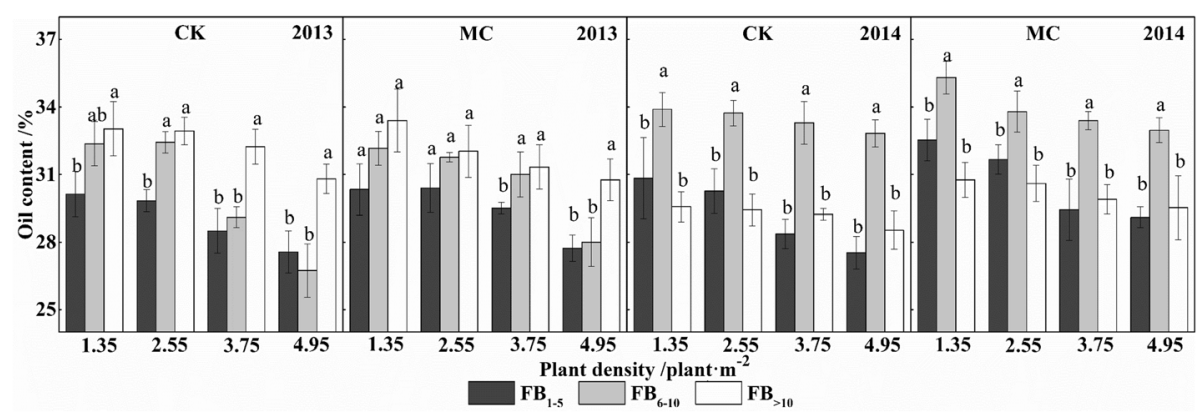

Fig. 1 Cottonseed oil content at different fruiting branches as affected by plant density and MC in Sikang 1 in 2013 and 2014

which might be an adaptation to light stress by high plant density. On the other hand, increasing plant density had an adverse effect on the number of fruiting branch and fruiting node (Table 1). These results were confirmed by Bednarz et al. and Heitholt, who found that plant density had a negative correlation with fruit branch number and boll setting percentage (Bednarz et al. 2000; Heitholt 1995).

The application of MC reduced plant height, fruit branch length, and fruit branch number, but not decreased final boll number per area (Tables 1 and 2). Previous studies showed that application of MC reduced cotton plant height (Mao et al. 2014; Pettigrew and Johnson 2005) and fruit branch length and increased boll setting rate (Mao et al. 2014). Obviously, applying $\mathrm{MC}$ resulted in a lower and more compact plant canopy, which is attributed to the effective control of $\mathrm{MC}$ in plant vegetative growth. Maximal cottonseed yield achieved at an optimal plant density depends on MC to control excessive vegetative growth (Sawan et al. 1993; York 1983).

Cottonseed yield showed a parabolic increase as plant density increasing, having the highest yield at 3.75 plants. $\mathrm{m}^{-2}$ (Table 2), which is a trade-off between the effects of plant density on boll number per unit area and 100 -seed weight. Similar to cottonseed yield, lint yield also showed a parabolic increase as plant density increasing (data not shown), having the highest yield at 3.75 plants $\mathrm{m}^{-2}$. Meanwhile, the observed positive influence of MC on cottonseed yield related to increases in both 100-seed weight and boll number per unit area (Table 3). In agreement with our result, the recommended population density of cotton for high lint yield in the Yangtze River Valley of China is $2 \sim 3$ plants. $\mathrm{m}^{-2}$ (Yang et al. 2014; Yang and Zhou 2010). Sawan (2014) reported that application of $\mathrm{MC}$ at the rates of 72 and $288 \mathrm{~g} \cdot \mathrm{hm}^{-2}$ resulted in a significant increase in cottonseed yield in two experiments, respectively. Application of MC can optimize canopy structure, restrict excessively vegetative growth and consequently increase boll setting percentage, and hence increase boll number per unit area as well as seed weight (Sawan 2014). York (1983) found that MC increased cotton yields in four of the eight locations when plant population ranged from 3.7 to 23.5 plants $\cdot \mathrm{m}^{-2}$. This may be associated with the interactions between environmental condition and the

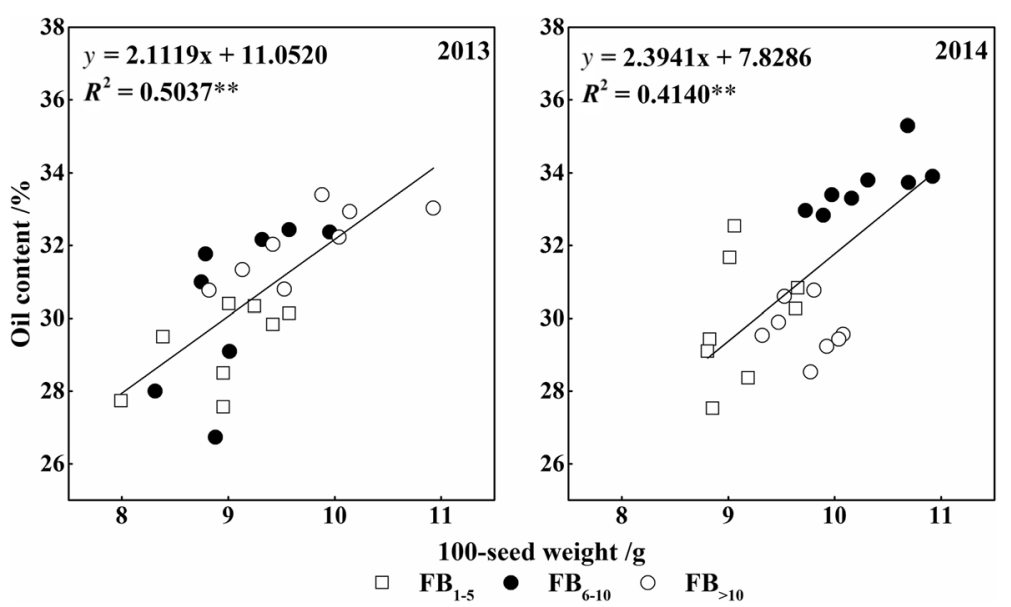

Fig. 2 Relationships between 100-seed weight and cottonseed oil content on different fruiting branches under plant density and MC treatment in Sikang 1 in 2013 and 2014 
Table 4 Effects of mepiquat chloride (MC) on cottonseed vigor characters under different plant densities in Sikang 1

\begin{tabular}{|c|c|c|c|c|c|c|c|c|c|}
\hline \multirow[t]{2}{*}{$M C$} & \multirow[t]{2}{*}{ Plant density /(plant $\cdot \mathrm{m}^{-2}$ ) } & \multicolumn{2}{|c|}{ Germination percentage /\% } & \multicolumn{2}{|c|}{$\begin{array}{l}\text { Fresh weight of seeding } \\
/\left(g \cdot \text { plant }^{-1}\right)\end{array}$} & \multicolumn{2}{|c|}{$\begin{array}{l}\text { Germination } \\
\text { index }(\mathrm{Gl})\end{array}$} & \multicolumn{2}{|c|}{$\begin{array}{l}\text { Vigor } \\
\text { index (VI) }\end{array}$} \\
\hline & & 2013 & 2014 & 2013 & 2014 & 2013 & 2014 & 2013 & 2014 \\
\hline \multirow[t]{4}{*}{ CK } & 1.35 & 52.7 a & $51.0 \mathrm{a}$ & $0.48 \mathrm{a}$ & $0.60 \mathrm{a}$ & $4.6 \mathrm{a}$ & $5.0 \mathrm{a}$ & $2.2 \mathrm{a}$ & $2.4 \mathrm{a}$ \\
\hline & 2.55 & $54.0 \mathrm{a}$ & $50.0 \mathrm{a}$ & $0.47 \mathrm{a}$ & $0.51 \mathrm{ab}$ & $4.1 \mathrm{a}$ & $4.2 \mathrm{a}$ & $2.0 \mathrm{a}$ & $2.1 \mathrm{a}$ \\
\hline & 3.75 & $50.0 \mathrm{a}$ & $44.0 \mathrm{a}$ & $0.46 \mathrm{a}$ & $0.52 \mathrm{ab}$ & $4.1 \mathrm{a}$ & 3.3 a & $1.8 \mathrm{a}$ & $2.0 \mathrm{a}$ \\
\hline & 4.95 & $38.0 \mathrm{~b}$ & $34.0 \mathrm{~b}$ & $0.43 \mathrm{a}$ & $0.41 \mathrm{~b}$ & $2.8 \mathrm{a}$ & $2.8 \mathrm{a}$ & $1.2 \mathrm{a}$ & $1.8 \mathrm{a}$ \\
\hline \multirow[t]{4}{*}{ MC $135 \mathrm{~g} \cdot \mathrm{hm}^{-2}$} & 1.35 & 72.7 a & $62.0 \mathrm{a}$ & $0.53 \mathrm{a}$ & $0.55 \mathrm{a}$ & $5.8 \mathrm{a}$ & $5.2 \mathrm{a}$ & $3.1 \mathrm{a}$ & $3.0 \mathrm{a}$ \\
\hline & 2.55 & $66.7 \mathrm{ab}$ & $60.0 \mathrm{ab}$ & $0.50 \mathrm{ab}$ & $0.60 \mathrm{a}$ & $5.8 \mathrm{a}$ & $4.8 \mathrm{a}$ & $2.9 \mathrm{ab}$ & $2.9 \mathrm{a}$ \\
\hline & 3.75 & $58.0 \mathrm{bc}$ & $54.0 \mathrm{~b}$ & $0.48 \mathrm{bc}$ & 0.53 a & $4.1 \mathrm{a}$ & $4.5 \mathrm{a}$ & $2.0 \mathrm{ab}$ & $2.2 \mathrm{a}$ \\
\hline & 4.95 & $54.0 \mathrm{C}$ & $48.0 \mathrm{C}$ & $0.45 \mathrm{c}$ & $0.55 \mathrm{a}$ & $3.9 \mathrm{a}$ & $3.4 \mathrm{a}$ & $1.8 \mathrm{~b}$ & $1.9 \mathrm{~b}$ \\
\hline \multicolumn{10}{|c|}{ Source of variance } \\
\hline \multicolumn{2}{|l|}{ Plant density } & * & ** & * & * & ns & ns & $*$ & * \\
\hline \multicolumn{2}{|l|}{$M C$} & * & * & * & * & ns & ns & * & * \\
\hline \multicolumn{2}{|c|}{ Plant density $\times$ MC } & ns & ns & ns & ns & ns & ns & ns & ns \\
\hline
\end{tabular}

Values followed by the different letters within the same column are significant differences at 0.05 probability level; ${ }^{*}$ and ${ }^{* *}$ represent significant differences at 0.01 and 0.05 probability level, respectively; ns represents no significant differences

range of plant density. While differently with our result, Ren et al. (1991) indicated that the recommended density of cotton for high cottonseed yield is 6.0 6.6 plants $\cdot \mathrm{m}^{-2}$ and optimum MC application rate is $75 \sim 90 \mathrm{~g} \cdot \mathrm{hm}^{-2}$ in Jiangsu. This may relate to the differences in cultivar, environmental condition and planting mode.

In the present study, no significant interaction was found between plant density and MC on cottonseed yield (Table 2), but the response of cottonseed yield to MC applying tended to be greater at high plant densities than at lower plant densities. Similarly, the study of York (1983) showed that a large increase in yield at higher population through MC application, since MC may alleviate the detrimental impacts of excessive vegetative growth caused by above optimum populations in cotton.

The cottonseed oil content was negatively related to plant density (Table 3), which was similar to results obtained by Zhu et al. (2010). Meanwhile, MC application significantly enhanced cottonseed oil content (Table 3).
The reason may partly be that cottonseed oil content was positively correlated with the activities of phosphatidate phosphatase (PPase) and glucose-6-phosphate dehydrogenase (G6PDH) (Shen et al. 2015). These enzyme activities usually significantly decrease under unfavorable environments (Shen et al. 2015; Xu et al. 2008) and thus lead to a lowered cottonseed oil content at higher plant densities. In addition, for all plant density treatments and MC treatments, cottonseed oil content was lower in 2013 than in 2014 (Table 3), which may be due to high air temperature during boll maturation phase in 2013. The average daily temperature in July and August in 2013 was $4.2^{\circ} \mathrm{C}$ higher than in 2014 (Table 5), too high or low temperature is not beneficial to cottonseed crude fat accumulation ( $\mathrm{Li}$ et al. 2009b). The responses of cottonseed protein content to increasing plant density and applying MC were relatively small and nonlinear. There is a need for further study to better understand how plant density and $\mathrm{MC}$ influence cottonseed protein content.

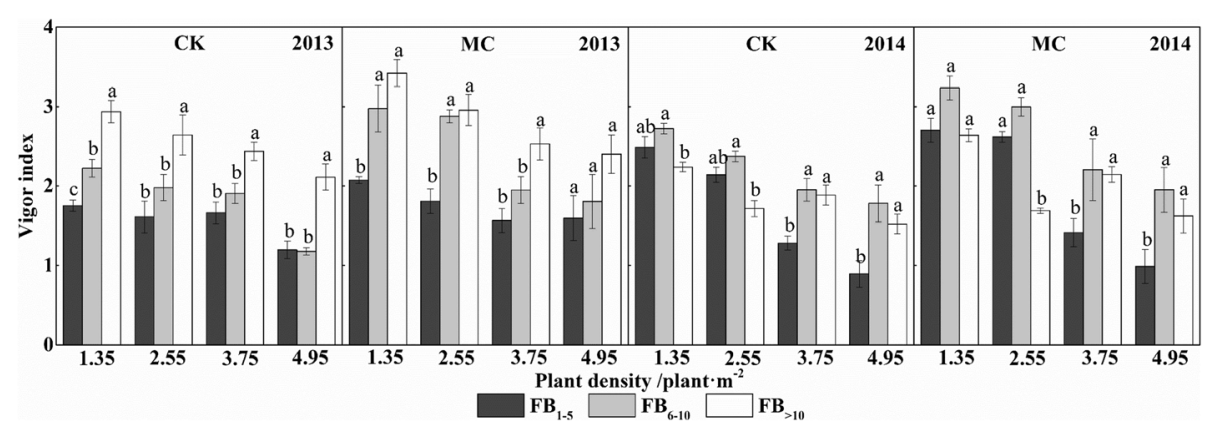

Fig. 3 Vigor index of cottonseed at different fruiting branches as affected by plant density and MC in Sikang 1 in 2013 and 2014 
Table 5 Meteorological factors during the cotton growth period at the experimental station in Dafeng, Jiangsu

\begin{tabular}{|c|c|c|c|c|c|c|}
\hline \multirow[t]{2}{*}{ Month } & \multicolumn{2}{|c|}{ Average temperature $/{ }^{\circ} \mathrm{C}$} & \multicolumn{2}{|c|}{ Precipitation /mm } & \multicolumn{2}{|c|}{ Heat units $/{ }^{\circ} \mathrm{C}$} \\
\hline & 2013 & 2014 & 2013 & 2014 & 2013 & 2014 \\
\hline April & 12.3 & 14.1 & 21.2 & 51.1 & -76 & -18 \\
\hline May & 18.9 & 20.2 & 96.0 & 79.1 & 137 & 173 \\
\hline June & 22.2 & 22.4 & 77.3 & 127.9 & 226 & 236 \\
\hline July & 29.8 & 25.9 & 207.5 & 113.8 & 474 & 353 \\
\hline August & 29.5 & 25.0 & 68.6 & 130.4 & 462 & 326 \\
\hline September & 22.6 & 22.6 & 57.8 & 195.8 & 237 & 237 \\
\hline October & 17.3 & 17.5 & 45.2 & 17.0 & 69 & 86 \\
\hline Average/total & 21.8 & 21.1 & 573.6 & 715.1 & 218 & 199 \\
\hline
\end{tabular}

Heat units were calculated from maximum and minimum temperatures as $\Sigma\left[\left(\right.\right.$ max. Temp. + min. Temp.) $\left./ 2-15^{\circ} \mathrm{C}\right]$. All data were collected from a weather station (Campbell AG800, Genetics, USA) located near the experiment field

All seed germination indicators decreased consistently as plant density increased under both $\mathrm{CK}$ and MC treatment while increased with MC application at all plant density treatments (Table 4). Dong et al. (2005) found that cottonseed maturity and germination percentage increased with plant density increasing at the range of 2.25 3.75 plants. $\mathrm{m}^{-2}$. This is inconsistent with our result, which may be associated with the range of plant density and different production areas. The beneficial effect of MC on seed germination was confirmed by several studies (Wang et al. 2010; Sawan 2013). For instance, Sawan observed that both 72 and $288 \mathrm{~g} \cdot \mathrm{hm}^{-2}$ MC application significantly increased cottonseed vigor (2013). Wang et al. also showed that MC increased cottonseed GP and VI (2010). Thus, optimizing plant density and MC application might be an effective measure to increase seed germination quality. It should be noted that the seed GP measured in this study are relatively low, which could be related to the paper rolling method adopted. The GP measured using paper rolling method is usually lower than that measured by sand culture method. Another reason is related to germination test timing. The GP of cottonseeds that do not finish afterripening might be low.

In addition, a significant positive correlation between 100 -seed weight and oil content was observed in this study (Fig. 2). And interestingly, the change trend of seed VI in different FBs across plant density and MC treatments was the same with the changes of cottonseed oil content (Figs. 1 and 3), indicating that vigor index is highly related to 100 -seed weight and cottonseed oil content. Generally, cottonseeds with larger volume and mass tend to content more storage material and have higher vigor, for a given variety. However, a study showed that 100 -seed weight was not significantly correlated to VI when data were analyzed among different cultivars (Zhou et al. 1992). The results may vary because of the difference in genetic characteristics of cottonseed.

\section{Conclusion}

Boll number per unit area of cotton significantly increased with increasing plant density, whereas 100 -seed weight, oil content and VI reduced under high plant density for CK and MC treatment. Cottonseed yield had the maximum value at 3.75 plants. $\mathrm{m}^{-2}$ with or without $\mathrm{MC}$ applying. The application of $\mathrm{MC}$ reduced plant height, mean fruiting branch length under different plant densities, resulting in a lower and more compact plant canopy. For all plant density treatments from 1.35 to 4.95 plants $\cdot \mathrm{m}^{-2}$, application of $\mathrm{MC}$ significantly enhanced cottonseed yield and quality by suppressing excessive vegetative growth, when MC was sprayed in four development stages at the total rate of $135 \mathrm{~g} \cdot \mathrm{hm}^{-2}$. These results suggested that higher plant density is not beneficial to cottonseed quality but increase cottonseed yield per unit area, and applying MC can promote both cottonseed yield and quality. Seed production benefit depends on whether plant density and MC management can improve the match between seed yield and quality. In the Yangtze River cotton growing region of China, planting cotton at 3.75 plants. $\mathrm{m}^{-2}$ and application of MC $\left(135 \mathrm{~g} \cdot \mathrm{hm}^{-2}\right)$ could achieve a compact plant structure and high cottonseed yield and quality.

\section{Methods \\ Experimental design}

A two-year field experiment was conducted at Dafeng Experimental Station $\left(33^{\circ} 24^{\prime} \mathrm{N}\right.$ and $\left.120^{\circ} 34^{\prime} \mathrm{E}\right)$, Dafeng, Jiangsu Province, China, in 2013 and 2014. The soil was sandy loam with a pH of 7.8 and 8.3 in 2013 and 2014, respectively. Before sowing, the $0-20 \mathrm{~cm}$ soil contains 9.7 and $9.5 \mathrm{~g} \cdot \mathrm{kg}^{-1}$ organic matter, 0.97 and $0.92 \mathrm{~g} \cdot \mathrm{kg}^{-1}$ total nitrogen $(\mathrm{N}), 22.9$ and $21.3 \mathrm{mg} \cdot \mathrm{kg}^{-1}$ available $\mathrm{N}$, 27.6 and $24.7 \mathrm{mg} \cdot \mathrm{kg}^{-1}$ available phosphorus (P), and 224.9 and $213.7 \mathrm{mg} \cdot \mathrm{kg}^{-1}$ available potassium (K), respectively, in 2013 and 2014. 
A split plot design with three replications was performed. Each subplot contained five rows, $11 \mathrm{~m}$ long with a row spacing of $1.1 \mathrm{~m}$. Sikang 1, widely-planted commercial cotton cultivar in the reaches of Yangtze River Valley in China, were sown in nutrition beds on April 15 and seedlings were transplanted to the field on May 15 in both 2013 and 2014. Two mepiquat chloride treatments (135 g.hm ${ }^{-2}$ of mepiquat chloride (MC), a commonly used dosage in the Yangtze River Valley of China, and water control treatment (CK)) was applied, respectively, to four plant densities of $1.35,2.55,3.75$ and 4.95 plants $\cdot \mathrm{m}^{-2}$. MC was sprayed in four developmental stages of cotton plant: squaring stage, initial flowering stage, flowering stage, and seven days after topping at dose of 7, 30, 45 and $53 \mathrm{~g} \cdot \mathrm{hm}^{-2}$ in each stage, respectively. In total of $40 \% \mathrm{~N}$ of $300 \mathrm{~kg} \cdot \mathrm{hm}^{-2}$ was applied basally before transplanting, and the remaining was applied when $50 \%$ of flowers on the first node of first fruiting branch bloomed. All plots received a basal rate of $67.5 \mathrm{~kg} \cdot \mathrm{hm}^{-2} \mathrm{P}_{2} \mathrm{O}_{5}$ and $150 \mathrm{~kg} \cdot \mathrm{hm}^{-2} \mathrm{~K}_{2} \mathrm{O}$ according to local practice.

\section{Plant sampling and measurements}

The continuous 10 plants in the central row of each plot were used for counting the fruiting branch number, boll number and fruiting node per plant at harvest. Plant height, first fruit branch height and fruiting branch length were measured with ruler. Plant height was measured from the cotyledonary node to the terminal. First fruit branch height was measured from the cotyledonary node to the first fruiting branch node. Fruiting branch length was measured from the bottom to the top of each fruiting branch.

When cotton bolls opened, boll number was recorded and 50 bolls were hand-harvested in each plot for assessment of seed number per boll, 100-seed weight, 100embryo weight and cottonseed yield. Cottonseed yield $\left(\mathrm{kg} \cdot \mathrm{hm}^{-2}\right)$ was determined by boll number per unit area $\times 100$-seed weight $\times$ seed number per boll / 100 .

Besides, 20 bolls from fruiting branches 1-5, 5-10 and $>10$ were separately hand-harvested in each plot for assessment of cottonseed oil content and vigor index, respectively.

Bolls and carpels were dried at $40{ }^{\circ} \mathrm{C}$ and biomass was weighed before ginning. After ginning, fuzzy seed was collected, acid-detinted and dried at $40{ }^{\circ} \mathrm{C}$ for further test. The shells, seeds and fiber were separated. The embryos dried at $105^{\circ} \mathrm{C}$ for $30 \mathrm{~min}$, and then at $60{ }^{\circ} \mathrm{C}$ to constant weight before grinded.

\section{Determination of cottonseed oil and protein contents}

Cottonseed oil content was measured using the Soxhlet extraction method (Luque de Castro and Garcia-Ayuso 1998). The cottonseed $\mathrm{N}$ concentration was determined using the method of Kjeldahl (Feil et al. 2005), and the protein content was calculated as $6.25 \times \mathrm{N}$ concentration (Li et al. 2009a).

Determination of cottonseed germination characteristics Seed germination tests were performed using the germination papers $(25 \mathrm{~cm} \times 38 \mathrm{~cm}, \mathrm{ANCHOR}, \mathrm{USA})$. Fuzzy seeds were arranged between double layered rolled germination papers which had been soaked with deionized water for $24 \mathrm{~h}$. Each roll contained 25 seeds, two rolls as one replication and there were three replications in total. Paper rolls with seeds were placed in a germination chamber (DGX-800E, Ningbo Haishu Safe Experiment Instrument Factory, China) at a constant temperature of $30{ }^{\circ} \mathrm{C}$ with $250 \mathrm{~mol} \cdot \mathrm{m}^{-2} \cdot \mathrm{s}^{-1}$ light intensity and a diurnal cycle of $8 \mathrm{~h}$ light and $16 \mathrm{~h}$ darkness for 9 days, using a $12 \mathrm{~cm} \times 18 \mathrm{~cm} \times 9 \mathrm{~cm}$ germination box. Germination was counted to be successful when the cotyledons flattened. The number of seeds germinated was recorded every $24 \mathrm{~h}$ for 9 days. Seedling fresh weight was measured at the end of germination. After 9 days, the germination percentage (GP, \%) is calculated using the equation: $\mathrm{GP}=100^{*}$ germinated seeds number at 9th day/50. In addition, germination index (GI) and vigor index (VI) are calculated as follows:

$$
\begin{aligned}
& \mathrm{GI}=\sum(\mathrm{Gt} / \mathrm{Dt}) \\
& \mathrm{VI}=\mathrm{GI} \times \mathrm{S}
\end{aligned}
$$

Where Gt denotes the germination number of germinated seed at the day $(\mathrm{t})$; Dt denotes the days from seed to seedling; $S$ denotes the fresh weight of seedlings at the 9 th day.

\section{Weather data}

Monthly average temperature, precipitation and heat units data, which obtained from a weather station (Campbell AG800, Genetics, USA) located near the experiment field were listed in Table 5. During the cotton growing season (from July 1 to September 30), average temperature, heat units and total precipitation were $27.3^{\circ} \mathrm{C}, 391^{\circ} \mathrm{C}$ and $333.9 \mathrm{~mm}$ in 2013 , and $24.5^{\circ} \mathrm{C}$, $305^{\circ} \mathrm{C}$ and $440.0 \mathrm{~mm}$ in 2014 , respectively.

\section{Data analysis}

The variance analysis was performed using Duncan's new multiple-range test in SPSS 17.0. All graphs were drawn with Origin 8.0 software. The means were analyzed using the least significant difference (LSD) test at $5 \%$ of probability level.

\section{Abbreviations}

CK: Water control treatment; FB: Fruiting branch; Gl: Germination index GP: The germination percentage (\%); MC: Mepiquat chloride; VI: Vigor index 


\section{Acknowledgements}

Not applicable.

\section{Authors' contributions}

Zhao WQ, Yan Q, Zhou ZG and Meng YL conceived and designed the experiment. Yang HK, Yang XN, Chen BL and Wang LR helped to conduct the experiments. Zhao WQ, Yan Q, and Yang HK collected and analyzed the data and prepared the draft. Meng YL revised the manuscript. All authors read and approved the final manuscript.

\section{Funding}

We acknowledge financial support from the Special Fund for Agro-scientific Research in the Public Interest (201503109), the Fundamental Research Funds for the Central Universities (KYYJ201802), Jiangsu Collaborative Innovation Center for Modern Crop Production (JCIC-MCP), and Jiangsu Overseas Research and Training Program for University Prominent Young and Middleaged Teachers and President (2016), China.

\section{Availability of data and materials}

The data and material are available.

\section{Ethics approval and consent to participate}

Not applicable.

\section{Consent for publication}

Not applicable.

\section{Competing interests}

The authors declare that they have no competing interests.

Received: 29 March 2019 Accepted: 17 June 2019

Published online: 19 July 2019

\section{References}

Almeida AQ, Rosolem CA. Cotton root and shoot growth as affected by application of mepiquat chloride to cotton seeds. Acta Scientiarum. Agron. 2012;34:61-5

Bednarz CW, Bridges DC, Brown SM. Analysis of cotton yield stability across population densities. Agron J. 2000;92:128-35.

Bednarz CW, Nichols RL, Brown SM. Plant density modifications of cotton withinboll yield components. Crop Sci. 2006;46:2076-80.

Bewley JD. Seed germination and dormancy. Plant Cell. 1997;9:1055-66.

Chen M, Zhao W, Meng Y, et al. A model for simulating the cotton (Gossypium hirsutum L.) embryo oil and protein accumulation under varying environmental conditions. Field Crops Res. 2015;183:79-91. https://doi.org/10. 1016/j.fcr.2015.07.011

de Faria GMP, da Silva Oliveira M, de Carvalho LP, et al. Gains from selection for oil content in cotton. Ind Crop Prod. 2013;51:370-5. https://doi.org/10.1016/j. indcrop.2013.09.005.

Dong H, Li W, Xin C, et al. Late planting of short-season cotton in saline fields of the Yellow River Delta. Crop Sci. 2010;50:292-300.

Dong $\mathrm{H}$, Zhang D, Tang W, et al. Effects of planting system, plant density and flower removal on yield and quality of hybrid seed in cotton. Field Crops Res. 2005;93:74-84.

Egelkraut TM, Kissel DE, Cabrera ML, et al. Nitrogen concentration in cottonseed as an indicator of $N$ availability. Nutr Cycl Agroecosys. 2004;68:235-42.

Feil B, Moser SB, Jampatong S, et al. Mineral composition of the grains of tropical maize varieties as affected by pre-anthesis drought and rate of nitrogen fertilization. Crop Sci. 2005:45:516-23.

Fu W, Su X, Qu Y, et al. Effects of planting density on seed yield and quality in conventional cotton breeding farm. Acta Agriculturae Boreali-occidentalis Sinica. 2015;24(2):79-83. (in Chinese with English abstract). https://doi.org/10. 7606/j.issn. 1004-1389.2015.02.014.

Guo B, Liu S, Wang K, et al. Correlation analysis of seed kernel oil content and major economic traits in cotton (Gossypium hirsutum L.). Cotton Sci. 2013;25: 365-71. (in Chinese with English abstract).

Gwathmey CO, Clement JD. Alteration of cotton source-sink relations with plant population density and mepiquat chloride. Field Crops Res. 2010;116:101-7. https://doi.org/10.1016/j.fcr.2009.11.019.

Heitholt JJ. Cotton flowering and boll retention in different planting configurations and leaf shapes. Agron J. 1995;87:994-8.
Hu W, Dai Z, Yang J, et al. Cultivar sensitivity of cotton seed yield to potassium availability is associated with differences in carbohydrate metabolism in the developing embryo. Field Crops Res. 2017;214:301-9. https://doi.org/10.1016/ j.fcr.2017.09.022.

Li F, Du M, Xu D, et al. Effects of chemical topping with fortified mepiquat chloride on cotton grwoth, yield and maturity under different plant densities and nitrogen rates in the Yellow River valley region of China. J of China Agri University. 2018;23(3):10-22.

Li W, Meng Y, Chen B, et al. Effects of climatic factors on fat and total protein content in cottonseeds. Acta Ecol Sin. 2009b;29:1832-9. (in Chinese with English abstract).

Li W, Zhou Z, Meng Y, et al. Modeling boll maturation period, seed growth, protein, and oil content of cotton (Gossypium hirsutum L.) in China. Field Crops Res. 2009a;112:131-40. https://doi.org/10.1016/j.fcr.2009.02.009.

Luque de Castro MD, Garcia-Ayuso LE. Soxhlet extraction of solid materials: an outdated technique with a promising innovative future. Anal Chim Acta. 1998:369:1-10.

Mao L, Zhang L, Zhao $X$, et al. Crop growth, light utilization and yield of relay intercropped cotton as affected by plant density and a plant growth regulator. Field Crops Res. 2014;155:67-76. https://doi.org/10.1016/j.fcr.2013. 09.021.

Mondino M, Peterlin O, Garay F. Response of late-planted cotton to the application of a growth regulator (chlorocholine chloride, CYCOCEL 75). Exp Agric. 2004;40:381-7. https://doi.org/10.1017/S0014479704002017.

Pettigrew WT, Johnson JT. Effects of different seeding rates and plant growth regulators on early-planted cotton. J Cotton Sci. 2005;9:189-98.

Rademacher W. Growth retardants: effects on gibberellin biosynthesis and other metabolic pathways. Annu Rev Plant Biol. 2000:51:501-31.

Rast LE. The oil content of cotton seed an accurate basis for commercial standardization. Science. 1917:45:507-8. https:/doi.org/10.1126/science.45.1169.507.

Reddy AR, Reddy KR, Hodges HF. Mepiquat chloride (PIX)-induced changes in photosynthesis and growth of cotton. Plant Growth Regul. 1996;20:179-83.

Ren X, Zhang L, Du M, et al. Managing mepiquat chloride and plant density for optimal yield and quality of cotton. Field Crops Res. 2013;149:1-10. https:// doi.org/10.1016/j.fcr.2013.04.014.

Ren $Y$, Song Q, Zhang J, et al. Combined effects of planting density, nitrogen fertilizer and mepiquat chloride on cotton seed yield. Jiangsu J of Agri Sci. 1991;7(S1):11-6.

Sawan ZM. Direct and residual effects of plant nutrition's and plant growth retardants, on cottonseed. Agric Sci. 2013;4:66-8. https://doi.org/10.4236/as. 2013.412A007.

Sawan ZM. Cottonseed yield and its quality as affected by mineral fertilizers and plant growth retardants. Agr Sci. 2014;5:186-209. https://doi.org/10.4236/as. 2014.53023.

Sawan ZM. Cottonseed yield and its quality as affected by mineral nutrients and plant growth retardants. Cogent Biol. 2016;2:1245938. https://doi.org/10. 1080/23312025.2016.1245938

Sawan ZM, Basyony AE, McCuistion WL, et al. Effect of plant population densities and application of growth retardants on cottonseed yield and quality. J Am Oil Chem Soc. 1993;70:313-7.

Sawan ZM, Hafez SA, Basyony AE. Effect of nitrogen fertilization and foliar application of plant growth retardants and zinc on cottonseed, protein and oil yields and oil properties of cotton. J Agron Crop Sci. 2001;186:183-91. https://doi.org/10.1046/j.1439-037X.2001.00473.x.

Shen T, Du X, Yang $H$, et al. Effects of double cropping of wheat and cotton on fat and protein metabolism of cotton embryo. Acta Agron Sin. 2015;41:123745. (in Chinese with English abstract).

Siebert JD, Stewart AM. Influence of plant density on cotton response to mepiquat chloride application. Agron J. 2006;98:1634-9.

Stansbury MF, Cucullu AF, Den Hartog GT. Cottonseed contents variation, influence of variety and environment on oil content of cottonseed kernels. J Agric Food Chem. 1954;2:692-6. https://doi.org/10.1021/jf60033a007.

Thomas TP, Birney DM, Auld DL. Optimizing esterification of safflower, cottonseed, castor and used cottonseed oils. Ind Crop Prod. 2013;41:102-6. https://doi.org/10.1016/j.indcrop.2012.03.023.

Tung SA, Huang Y, Ali S, et al. Mepiquat chloride application does not favor leaf photosynthesis and carbohydrate metabolism as well as lint yield in lateplanted cotton at high plant density. Field Crops Res. 2018;221:108-18. https://doi.org/10.1016/j.fcr.2018.02.027.

Wang L, Mu C, Du M, et al. The effect of mepiquat chloride on elongation of cotton (Gossypium hirsutum L.) internode is associated with low 
concentration of gibberellic acid. Plant Sci. 2014;225:15-23. https://doi.org/10. 1016/j.plantsci.2014.05.005.

Wang Y, Li W, Dong H. Effects of different chemical treatments on germination and salt resistance of cotton seeds. Shandong Agricultural Sci. 2010;3:73-6. (in Chinese with English abstract).

Xing J, Zhang S, Zhao X, et al. Interaction of plant density with mepiquat chloride affects plant architecture and yield in cotton. Cotton Sci. 2018;30(1): 53-61. (in Chinese with English abstract). https://doi.org/10.11963/1002-7807. xjzlz.20171201.

Xu Y, Guan C, Tan T, et al. Changes of oil content and oil biosynthesis-related enzymes activities and their correlation during seed formation in Brassica napus. Acta Agron Sin. 2008;34:1854-7. (in Chinese with English abstract).

Yang G, Luo X, Nie Y, et al. Effects of plant density on yield and canopy micro environment in hybrid cotton. Journal of Integrative Agri. 2014;13(10):215463. https://doi.org/10.1016/S2095-3119(13)60727-3.

Yang G, Zhou M. Multi-location investigation of optimum planting density and boll distribution of high-yielding cotton (G. hirsutum L.) in Hubei Province, China. Agric Sci in China. 2010;43(9):1749-57. (in Chinese with English abstract). https://doi.org/10.1016/S1671-2927(09)60273-X .

York AC. Response of cotton to mepiquat chloride with varying $\mathrm{N}$ rates and plant populations. Agron J. 1983;75:667-72.

Zhao Y, Guo R. Research progress on oil content of cottonseed and feasibility of high oil content breeding in upland cotton (Gossypium hirsutum L.). Cotton Sci. 2011;23(2):184-8. (in Chinese with English abstract).

Zhou T, Cai Y, Wu N, et al. Association between seed vigour and physical properties in upland cotton. J Anhui Agric College. 1992;19:279-84. (in Chinese with English abstract).

Zhu L, Zhou Z, Zhao W, et al. Effects of plant densities on cottonseed biomass, fat and protein contents. Acta Agron Sin. 2010;36(12):2162-9. (in Chinese with English abstract). https://doi.org/10.3724/SP.J.1006.2010.02162.

Ready to submit your research? Choose BMC and benefit from:

- fast, convenient online submission

- thorough peer review by experienced researchers in your field

- rapid publication on acceptance

- support for research data, including large and complex data types

- gold Open Access which fosters wider collaboration and increased citations

- maximum visibility for your research: over $100 \mathrm{M}$ website views per year

At $\mathrm{BMC}$, research is always in progress.

Learn more biomedcentral.com/submissions 